Ks. MARIAN STASIAK*

\title{
Prawo W SŁUŻBie humanizacji ŻyCia
}

\section{Wstęp}

Opinia publiczna w naszym kraju koncentruje aktualnie swoją uwagę na treściach informujących o przebiegu sądownictwa w Polsce. W środkach masowego przekazu dominują kwestie z zakresu nowelizacji porządku prawnego, przebudowy struktur sądownictwa, usprawnienia procedur sądowych. Realizuje się tym samym przyspieszona edukacja społeczeństwa, które dostrzega coraz wyraźniej wartość życiową prawa $\mathrm{w}$ państwie i rozbudza zarazem większe oczekiwania związane z prawem ${ }^{1}$.

* Dr hab., prof. KUL, emerytowany profesor Wydziału Prawa, Prawa Kanonicznego i Administracji Katolickiego Uniwersytetu Lubelskiego Jana Pawła II.

1 Jak wiadomo, postawy naszej kultury prawnej opierają się na jurysprudencji rzymskiej, w której na określenie pojęcia prawa używa się dwóch terminów ius i lex. We współczesnej nauce prawa problem różnicy między ius i lex podlega różnym interpretacjom w zależności od przyjętych założeń teoretycznych i filozoficznych. Ogólnie ius uznawane jest najczęściej jako synonim prawa w ogóle, jako idea prawa, natomiast lex utożsamia prawo powstałe na mocy decyzji organu prawotwórczego, jako akt normatywny, prawo stanowione, pisane obowiązujące. Różnica ta znajduje odzwierciedlenie w różnych językach, jak np. w angielskim (right i law), francuskim (droit loi), włoskim (diritto i legge), niemieckim (Recht i Gesetz), polskim (prawo i ustawa). W zależności od kontekstu ten artykuł uwzględnia oba znaczenia terminu prawo. 


\section{Ambiwalentne podejście do prawa}

Zazwyczaj wiedza z zakresu prawa ogranicza się w wielu kręgach społecznych do niewielkiego zasobu obiegowych pojęć i subiektywnego doświadczenia wyniesionego $\mathrm{z}$ konfrontacji z prawem na forum sądu. Wyrok rozstrzygający spór, jak wiadomo, daje zwycięstwo jednej ze stron, druga pozostaje $\mathrm{w}$ pozycji przegranej. Obraz prawa, na którym obywatel skupia swoją uwagę, rysuje się zatem w liniach uproszczonych i wycinkowych. Ilustrują to postawy społeczne w spojrzeniu na fenomen prawa i wypowiedzi wskazujące na ocenę jego przydatności jako regulatora życia społecznego. W tym kontekście można z łatwością wskazać na dwa różne ujęcia kontrastujące ze sobą ${ }^{2}$. Odbija się w nich ambiwalentne podejście do prawa.

Faktycznie z jednej strony prawo jest pojmowane przez obywateli jako byt zewnętrzny w relacji do osoby, narzucony przez system władzy, ograniczający wolność i autonomię osoby, a zarazem represyjny, stanowiący narzędzie $\mathrm{w}$ rękach mocniejszego. W rezultacie prawo objawia się jako instrument zmanipulowany, podległy założeniom ideologii tych, którzy dzierżą władzę. Stąd spotyka się obiegowe utyskiwania na prawników, nie szczędzi się im uszczypliwości, zarzuca się kultywowanie legalizmu, spojrzenie na życie w cieniu suchych paragrafów.

Z drugiej zaś strony spotyka się podejście zupełnie odmienne, prawo traktowane jest jako niezbędny instrument stanowiący gwarancję społecznego ładu, nakładając ograniczenia dla subiektywnych interesów, warunkując tym samym pokojowe współżycie obywateli. Prawo powstaje w służbie sprawiedliwości, zapewnia zachowanie równowagi w relacjach międzyosobowych. Staje się zatem istotnym wyznacznikiem stabilizującym życie społeczne i ponadto okazuje się być gwarantem rozwoju społeczeństwa oraz nośnikiem optymizmu na jego lepszą przyszłość̉

2 Doświadczenie prawa jako fenomen życiowy objawia się także w Kościele, gdzie poziom napięcia przenosi się między pozytywistycznym ujęciem prawa zmonopolizowanym przez państwo a prawem ewangelicznym. Zob. m.in. L. Gerosa, Esperienza del diritto ed esperienza di fede al banco di prova di un nuovo manuale di diritto canonico, Rivista Teologica di Lugano 1(1998), s. 135-149.

3 Już w XII w. Aelredo di Rievaulx w dialogu Amicizia spirituale słusznie zauważył, iż księgi oświetlają życie, lecz o wiele bardziej karmią się życiem. Aelredo di Rievaulx, L'Amicizia Spirituale, Introduzione, Traduzione e Commento di D. Pezzini, Milano 1996, s. 56: „I libri, dunque, illuminano la vita, ma tanto più di vita si nutrono". 
Znana sentencja głosi: ius sequitur vitam - prawo podąża za życiem, które nie zna zastoju, jest stale dynamiczne ${ }^{4}$.

Nad całością wymienionych postaw dominuje wszakże szacunek i respekt dla prawa. Prawników ceni się głównie za ich wrażliwość na uznane społeczne wartości i za wysiłek przekuwania tych wartości w realia życia społecznego. W sytuacjach krytycznych wobec prawa poszukuje się zaś prawników, ucieka się z prośbą o ich pomoc. Prawo bowiem jawi się jako dobro istotne w wymiarze jednostkowym i społecznym, jako wartość, która okazuje się być wiernym towarzyszem człowieka w jego historii osobistej i całych dziejach. Stąd historia prawa to także historia dziejów ludzkości ${ }^{5}$.

\section{Prawo wiernym towarzyszem człowieka}

Historia to przestrzeń, w której wypełnia się istnienie doczesne każdej osoby. Realizuje się ono na wielu poziomach, takich jak porządek etyczny, społeczny, religijny i prawny. Pośród tych porządków szczególne znaczenie posiada prawo ${ }^{6}$. Każdy człowiek, każda społeczność świadomie lub nieświadomie żyje $\mathrm{w}$ prawie. Prawo to powszechnie obecne

4 Problem ten podejmuje m.in K. Burczak, Ius sequitur vitam as a principle of evolution and revision of the law, w: Hodie et Cras, Today and Tomorrow of the 1983 Code of Canon Law Thirty Years after Promulgation, Lublin 2015, s. 129: „On the other hand, Ius constitutum has a variable nature lik eman, its creator homo viator, filling their social tasks and striving to achieve the salvific reality. However, "with the lapse of time, low no longer fits with the social requirements [...] it must be adepted to the new needs".

5 Prawo nie jest nigdy rodzajem chmury, która unosi się nad horyzontem historii. Ono stanowi jego komponent fundamentalny i charakteryzujący. Objawia się w wieloraki sposób zanurzony w tkankę społeczną, ekonomiczną i polityczną, lecz jego siła porządkująca nie może być oderwana od samego życia. Zob. m.in. P. Grossi, Prima Lezione di diritto, Edizioni Laterza 2003, s. 44: „Genesi, manifestazione, interpretazione, applicazione: tutto questo é diritto quale realtà, incarnata nella storia; genesi e applicazione - i due momenti estremi del processo giuridico - sono momenti non scomponibili di processo squisitamente unitario".

${ }_{6}^{6}$ W najstarszych źródłach prawa, a także w Starym Testamencie ukazana jest jego dynamika. Rzymianie normy zachowania łączyli z ich wymogiem praktycznym: „ius suum” wiązali z czasownikiem "tribuere”. Szerzej I. Kupiszewski, Prawo rzymskie, a wspótczesność, Warszawa 1988, s. 16-31. 
doświadczenie tworzone przez człowieka i dla człowieka7. Mówiąc najprościej, człowiek żyje prawem. Jego fundament opiera się na jednakowej i niezbywalnej godności osoby ludzkiej. Człowiek posługuje się prawem w najważniejszej grze o pełnię swojego człowieczeństwa, o kształt swojej przyszłości. W osobie ludzkiej prawo znajduje zatem swój najgłębszy, metafizyczny fundament i pierwotne źródło tego, co prawo stanowi w zakresie współżycia społecznego ${ }^{8}$, stąd naszą uwagę skupiamy na prawie ${ }^{9}$.

W cywilizacji europejskiej prawo zawsze stanowiło wartość wysoko cenioną, wypracowaną przez wkład myśli greckiej, wyróżniającej prawdę i fałsz przez realizm życiowy Rzymian, wartościujący to, co ważne od mniej ważnego, a także przez chrześcijańskie rozróżnienie dobra i zła. Na tych podwalinach powstał gmach prawa europejskiego ${ }^{10}$. Nie tylko w przeszłości, lecz także dzisiaj w prawie dostrzega się kluczowy regulator wielu dziedzin życia społecznego. Bez prawa nie sposób dokonywać konsolidacji więzi społecznych, wzmacniać struktury nie tylko państwowe, lecz także tworzyć organizm określany jako wspólnota narodów.

W tym kontekście warto dodać, iż w religii chrześcijańskiej prawo to nie tylko relacje międzyosobowe, to także odniesienie człowieka do Boga ujęte w kategoriach prawnych. Objawienie Boże, jego przymierze z ludź$\mathrm{mi}$, nazwano prawem, prawem najwyższym, płynącym z woli Boga.

7 W. Waldstein, Teoria Generale del Diritto, Dall' antichita ad oggi, Pontificia Università Leteranense 2001, s. 263: „[...] Nella loro essenza si tratta sempre di quei principi quarum causa omne ius constitutum est (Hermog. D. 1,5,2: Cum igitur hominum causa omne ius constitutum sit [...]). Noi troviamo questi negli ordinamenti giuridici dell'antichità come ratio scripta della convivenza umana, noi troviamo questi anche nelle codificazioni dell' Ottocento che erano state concepite esattamente per stabilire la validità di tali principio in articoli; oggi noi troviamo questi in modo più solenne nelle costituzioni moderni. [...] Di fronte a questi principi gli organi della Comunità devono nella loro attività arrestarsi con rispetto [...]".

8 S. Lener, Coesistenza e società: fondamento ontologico dell diritto, Civilta Cattolica 134(1983), s. 31: „In questa dignità, che e insieme realtà ontologica, sommo volare storico e sociale, primo e assoluto principio etico, sta appunto il fondamento metafisico del diritto".

9 Warto zaznaczyć, iż jurysprudencja nie osiągnęła dotąd zgody odnośnie do założeń, na podstawie których można definiować prawo w sposób ogólnie przyjęty. Problem nie jest nowy, gdyż już prawnicy rzymscy nie przywiązywali wagi do definicji prawa. Stąd znane powiedzenie zawarte w Digestach: „Omnis definitio in iure pericolosa est: parum est enim, ut non subverti poset". (Wszelka definicja w prawie jest niebezpieczna, niewiele jest bowiem takich, których nie można by obalić).

10 Szerzej R. Sobański, Prawo w Europie, Śląskie Studia Historyczno-Teologiczne 31(1998), s. 145-156. 
Widoczne jest zatem, jak inspiracja religii chrześcijańskiej torowała nowe ścieżki, na których rozwijał się dorobek prawa europejskiego i następował zarazem wyraźny postęp w humanizacji życia Europejczyków ${ }^{11}$.

W sposób wyraźny postęp ten objawia się nie tylko od początków pierwszego tysiąclecia, kiedy to odwołanie się do prawa rzymskiego sprawiło uwolnienie od poddaństwa i gwarantowało ochronę mienia niektórych warstw społecznych. Papież Grzegorz IX w bulli Rex pacificus promulgującej pierwszy urzędowy zbiór prawa kościelnego stwierdził:

Ideoque lex proditur ut appetitus noxius sub iuris regula limitetur, per quam genus humanum, ut honeste vivat, altrum nonlaedat, ius suum uniquique tribuat, informatur ${ }^{12}$.

Także i dziś prawo stanowi kluczowy regulator życia społecznego. Konstytucyjny porządek nowożytnego państwa odwołuje się, jak wiadomo, do podstawowych wartości obywatelskich, gwarantuje wolność i równość niezależnie od pozycji społecznej, stanu majątkowego, pochodzenia czy wyznawanej religii ${ }^{13}$. Prawo staje się własnością wszystkich ${ }^{14}$.

11 Na nowość prawa ewangelicznego wskazują ewangeliści w wielu miejscach, jego serce stanowi tzw. kazanie na górze i błogosławieństwa Jezusa (Łk 6,1-11; Mt 5,17-49). John L. McKenzie (Readings, Cases, Materials in Canon Law, a textbook for Ministerial Students, Revised Edition, red. J. Hite, D.J. Ward, Collegeville 1990, s. 3) tak komentuje: „What he proclaimed was not a new interpretation of law. In the Sermon on the Mount we find that passage called the Antitheses, «You have heard... I say to you» this passage is introduced by a declaration that Jesus has come not to destroy the law but to fulfill it, and that he that does and teaches the commandments is great in the Reign of God. [...] The law touches only the external act. The moral teaching of Jesus teaches the interior dispositions, the heard; it is here that true «cleanliness» is to be found. Aclean heart goes beyond the prescription of the law; and a clean heart is judged by the acts which the persons perform".

12 R. Sobański, Prawo moralne a procesy prawotwórcze demokratycznego państwa prawa, Śląskie Studia Historyczno-Teologiczne, 29(1996), s. 258.

13 Literatura w tym przedmiocie jest bardzo bogata, korzystałem m.in. z M. Fioravanti, Costituzione, il Mulino, Bologna 1999, także Istitutio Italiano per gli studi Filosofici, I valori della Costituzione Italiana, Atti del Convegno La Costituzione della Repubblica oggi, Principi da custodire, Istituti da Riformare, Napoli 20 Maggio 1995, red. S. Marotta, La Città del Sole 1996.

14 Stanowisko Konferencji Episkopatu Polski w sprawie założeń aksjologicznych do nowej konstytucji z 16 czerwca 1990 r. wskazuje na relacje pomiędzy obywatelem a państwem. Zob. J. Krukowski, Kościót i państwo. Podstawy relacji prawnych, Lublin 1993, s. 279: „Stosunek między jednostką, a państwem ma fundamentalne znaczenie dla życia i rozwoju każdej osoby, jak i całej zbiorowości. Wartością pierwotną w tej relacji jest człowiek, a państwo, podobnie jak i inne instytucje mają tworzyć ramy dla spełnienia przez 
Humanizacja życia przejawia się poprzez wyzwalającą funkcję prawa. Stanowi ono wsparcie dla słabszych, człowiek nie musi bronić swojej pozycji siłą, jego miejsce $\mathrm{w}$ społeczeństwie gwarantuje mu prawo. $\mathrm{W}$ nim znajduje oparcie i do niego może się odwołać. Ten wielki projekt myśli prawniczej w swym długim rozwoju doprowadził do tego, iż w sytuacjach konfliktowych wygaszony został dźwięk broni na polach walki znany zwrot "ut silent armae". Jego miejsce przejmuje prawo ${ }^{15}$. Procesy humanizacji prawa przejawiają się $\mathrm{w}$ istocie $\mathrm{w}$ tym, że jest ono tworzone przez człowieka i dla człowieka, jakim jest, podejmują zarazem wysiłek, aby wyzwalać go od tego jakim jest, rzeźbić na jego obliczu bardziej ludzkie rysy. Dzieje się to wówczas, gdy człowiek nie pozostaje obojętny na los drugiego, gdy objawia swoją wrażliwość wobec biedy materialnej i duchowej, gdy nie deprecjonuje innych osób nawet przez fakt, iż sam jest poszkodowany i uwikłał się w taki los, sięgając np. po narkotyki.

Realizm prawa, wspomniany uprzednio, objawia się tym, iż liczy się ono ze skażoną naturą człowieka, uwzględnia sytuację życiową, w której się znalazł, w prawie upatruje on dla siebie narzędzie ratunku - „Natura iuris ab hominum repetenda est natura"16. Dodać należy, iż chrześcijanin w wizerunku osoby ludzkiej nie zapomina o skazie grzechu pierworodnego ${ }^{17}$.

Prawo nie stanowi jakiegoś doskonałego remedium na ludzkie słabości, jest wszakże dziełem ludzkim, o ograniczonych możliwościach, niemniej wysoko cenionym. Prawo nie zmienia człowieka, nie walczy z jego miłością własną, akceptuje człowieka w prawdzie, bazuje zatem na fakcie, iż człowiek jest istotą myślącą i wolną, że dąży ze wszystkich sił do zabezpieczenia swojego przeżycia. Potrafi zatem włączyć miłość własną

człowieka jego przymiotów, realizacji jego przyrodzonych praw. Ów wtórny wobec osoby ludzkiej charakter instytucji życia zbiorowego nie przeczy temu, że są one niezbędne dla pomyślności jednostki i w tym sensie stanowią wartości wymagające ochrony".

15 Konstytucja soborowa Gaudium et Spes (n. 25) naucza: „Z natury społecznej człowieka wynika, że istnieje wzajemna zależność między postępem osoby ludzkiej i rozwojem społeczeństwa. Osoba ludzka jest i powinna być zasadą, podmiotem i celem wszystkich urządzeń społecznych, ponieważ z natury swej koniecznie potrzebuje ona życia społecznego".

16 Realizzare insieme un "progetto d'uomo" veramente umano, La Civiltà Cattolica 132(1981), nr 1, s. 3-14.

17 "Cały rodzaj ludzki jest w Adamie sicut unum corpus unius hominis - jak jedno ciało jednego człowieka. Przez tę jedność rodzaju ludzkiego wszyscy ludzie są uwikłani w grzech Adama, jak wszyscy są objęci sprawiedliwością Chrystusa. Przekazywanie grzechu pierworodnego jest jednak tajemnicą, której nie możemy w pełni zrozumieć". Katechizm Kościoła Katolickiego, Pallottinum 1994, n. 404. 
i zapędy egoizmu w rozwiązania prawne, w których racjonalnie przewiduje szanse na uniknięcie wojny wszystkich ze wszystkimi. Mówiąc prościej, człowiek w tworzeniu prawa zachowuje realizm.

\section{Człowiek chce być sobą}

Podejmując wysiłek tworzenia prawa, szukając procedur organizacji życia, musi nam przyświecać jakaś idea, która odsłania i nadaje sens tym wysiłkom. Refleksja tego rodzaju przenosi naszą uwagę na te idee, którymi karmiło się prawo w przeszłości, gdyż historia prawa to historia idei. ${ }^{18}$

Przebieg sporów wokół idei prawa odzwierciedla kręte meandry rzeki, których nie sposób tu nawet prześledzić. Pomimo to w całym biegu dziejów prawa wyłania się wyraźnie jedna dominująca myśl. Myśl, która jak zwornik w architekturze spina cały gmach dorobku myśli prawnej, wyraża się ona w stwierdzeniu, iż człowiek chce być sobą. To genialne w swej treści proste sformułowanie sięga rodowodem już na sześć wieków przed Chrystusem. Anaksymander z Miletu doszedł do wniosku, że z istnieniem człowieka wiąże się jego prawo do jego istnienia we własnej tożsamości ${ }^{19}$.

Mimo upływu wieków w wywodach dzisiejszych teoretyków prawa i twórców prawa konstytucyjnego rozbrzmiewa nader wyraźnie echo słów mędrca z Miletu. Wsłuchujemy się w jego brzmienie choćby wówczas, gdy we współczesnym prawie konstytucyjnym domagamy się konstytucyjnego umocowania prawa do sprzeciwu sumienia ${ }^{20}$. Człowiek

18 Jak zauważa H.J. Berman (Diritto e rivoluzione. Le origini della tradizione giuridica occidentale, Società editrice il Mulino 1998, s. 18): „Nella storia, modelli e regolarità possono essere necessari - nonostante trascendano i fatti - perché senza di essi non ci sarebbe la storia, mentre discontinuità radicali non sono necessarie, ma artificiose. „La natura non compie salti" (w historii wzorce i regulacje mogą okazywać się niezbędne, brak ciągłości jest wszakże sztuczny gdyż: „La natura non compie salti”. Natura nie dokonuje skoków). Książka ukazała się także w języku polskim: Prawo i rewolucja. Kształtowanie się zachodniej tradycji prawnej, Warszawa 1995.

19 R. Sobański (Prawo: wyzwolenie czy ucisk?, Chrześcijanin w Świecie, 26(1997), nr 3(204), s. 41-52) w kontekście przesłania tego mędrca z Miletu akcentuje, iż: „Człowiek ma prawo być demiurgiem własnego życia, a prawo państwowe ma nie tylko się z tym liczyć, ale temu właśnie służyć”.

20 Problem sprzeciwu sumienia doczekał się wielu opracowań, do ważniejszych należy: R. Bertolino, L'obiezione di coscenza moderna. Per una fondazione del diritto di obiezione, 
chce być sobą, pragnie być panem własnego życia, zabiega o to, aby samodzielnie kształtować własny los. Samorealizacja człowieka dokonuje się w wolności, aby mając możliwość wyboru, posiadać: „dominium super actus suos, dominium super se ipsum". Człowiek wiąże z prawem wysoko ustawione oczekiwania.

$\mathrm{Na}$ tym założeniu bazują właśnie konstytucje demokratycznych państw, zbieżne jest z nim także nauczanie Kościoła, wedle którego człowiek ustawiony na szczycie stworzenia ma prawo i obowiązek realizować się we własnej tożsamości. Kategoria osoby z jej niezbywalną godnością, jako centrum i szczyt prawa, warunkuje zatem nasze pojmowanie prawa. W tym podejściu prawo nie jest celem, lecz środkiem do realizacji w pełni osoby w jej niepowtarzalnej tożsamości. Prymat osoby ludzkiej oświetla zatem najpełniej rolę prawa $w$ humanizacji życia ${ }^{21}$. Z racji dobra osoby prawo porządkuje harmonijne odniesienie się ludzi między sobą, proteguje rozwój człowieka, legitymuje najpełniej obecność prawa w życiu społecznym na bazie sprawiedliwości.

\section{Prawo sprawiedliwe}

Właściwa kompozycja stosunków międzyosobowych bazuje na fundamentalnej przesłance, która w jednakowy sposób i w jednakowej mierze respektuje godność osoby ludzkiej jako podmiotu tych relacji.

Torino 1994. Stanowi także treść encykliki papieża Jana Pawła II Evangelium vitae, Acta Apostolicae Sedis 87(1995), s. 401-532.

21 Papież Jan Paweł II 3 kwietnia 1982 r. podczas Sympozjum Międzynarodowego Dalla Rerum Novarum alla Laborem Exercens powiedział m.in., iż człowiek w swojej godności ludzkiej winien stanowić głęboką inspirację i silną dynamikę dla wszystkich poszukiwań stosownych rozwiązań problemów społecznych. Człowiek pozostaje decydującym kryterium dla świata, który chce się budować w sprawiedliwości i w pokoju. Z takiej globalnej wizji osoby ludzkiej winny wynikać zasady refleksji, normy do oceny sytuacji i struktur, dyrektywy dla aktywności respektującej prawdę („L'uomo stesso, la dignità della sua umanità, deve costituire l'ispirazione profonda e la forza dinamica per ogni ricerca di soluzione adeguata ai problemi della società. L'uomo resta il criterio decisivo per un mondo che si voglia costruire nella giustizia e nella pace. Da tale visione globale della persona umana dobbono svilupparsi i principi di riflessione, le norme di giudizio circa situazioni e strutture, le direttive per un' azione rispettosa della verità"). Insegnamenti di Giovanni Paolo II, V. 1, Città del Vaticano 1982, s. 1097. 
Stwierdzenie to wywodzi się z elementarnej koncepcji sprawiedliwości i mocno zadomowione jest w myśli prawnej od czasów Ulpianusa, w której eksponuje się akcent wolitywny, niezmienną gotowość woli do świadczenia tego, co się należy wobec drugich ${ }^{22}$. W realizacji sprawiedliwości bowiem należy oddać to, co się każdemu należy. Ilekroć stwierdzamy: „mam prawo", uznajemy prawo za swoje, za cenną wartość. Wypowiedź "mam prawo" wyraża stan posiadania, deklarując zarazem, iż zachowuję się sprawiedliwie, bądź zgłasza roszczenie, by druga osoba zachowała się sprawiedliwie, by została oddana należna mi sprawiedliwość. Widać zatem, iż chodzi o sytuację, w której dominuje przeświadczenie, że człowiek winien być sprawiedliwy.

Spór o prawo rodzi prawo, daje rozstrzygnięcie: ius est dictio iuris. Spór ten, podkreślmy, powoduje zarazem potrzebę znalezienia środków dochodzenia do rozstrzygnięcia sporów. Prawo materialne, to „mam prawo" bez prawa formalnego, czyli bez procedur służących jego dochodzeniu nie jest $\mathrm{w}$ stanie stworzyć porządku prawnego, pozostaje czystą deklaracją. Zatem prawo materialne i procedury prawne to narzędzie sprawiedliwości, to środek realizacji sprawiedliwości w realiach życia ${ }^{23}$.

Trzeba podkreślić, iż cytowana powszechnie definicja Ulpiana ujmuje sprawiedliwość jako stałą wolę udzielania każdemu tego, co mu się należy. Akcent spoczywa na woli człowieka w jego odniesieniu do drugiego człowieka. Ta wola sprawia, iż człowiek w obejściu z innymi ludźmi chce być sprawiedliwy. Jak widać, wola bycia sprawiedliwym to fundamentalne założenie dla prawa. Gdy ludzie pragną być sprawiedliwi, prawo w pełni objawia swoją wartość jako dobro wysoko cenione, stanowi bowiem skuteczne narzędzie w kształtowaniu sprawiedliwego społeczeństwa $^{24}$. I vice versa, gdy brakuje woli bycia sprawiedliwym, prawo staje się

22 "Iustitia est constans et perpetua voluntas ius suum cuique tribuens". D. I.I.I.10.

23 Zachodzi tu wzajemne sprzężenie pomiędzy prawem materialnym, które stanowi ujęcie wartości w prawie, i prawem proceduralnym, zabezpieczającym realizację tych wartości. Bez sprzężenia tych dwóch elementów dochodzi do nadużyć i stąd trudno mówić o prawie. Szerzej zob. A. Spadaro, Contributo per una teoria della costituzione, w: Fra democrazia relativista e assolutismo etico, Milano 1994.

${ }^{24}$ Okazuje się więc, iż sprawiedliwość realizuje się w układzie wzajemnych odniesień, co z kolei opiera się na solidarności wyrażonej w osobistej odpowiedzialności za wszystkich. Jak naucza Jan Paweł II w encyklice Sollicitudo rei socialis (n. 38): „,solidarność jest to mocna i trwała wola angażowania się na rzecz dobra wszystkich i każdego, wszyscy bowiem jesteśmy naprawdę odpowiedzialni za wszystkich". 
bezużyteczne, a w skrajnych przypadkach pod kamuflażem prawa kryje się przemoc i tyrania.

Wobec powyższego sprawiedliwość ukazuje się jako zasada, na której wspiera się cała architektura życia społecznego, ona sprawia, że życie ludzkie jest harmonijne i twórcze. Znany aksjomat głosi: iussum quia iustum. Co więcej, relacje międzyludzkie są nie tylko kształtowane przez sprawiedliwość ${ }^{25}$, lecz zarazem to sprawiedliwość weryfikuje, czy te stosunki międzyosobowe wyrastają ze sprawiedliwości i czy bezwarunkowo dotyczą wszystkich: erga omnes ${ }^{26}$.

Z tego wynika, że porządek prawny winien być w swoich treściach formowany według zasad sprawiedliwości, prawo stanowi bowiem uprzywilejowane miejsce dla aktualizacji sprawiedliwości.

Niezbędne jest zaznaczyć, iż w refleksji nad stosunkiem prawa do sprawiedliwości prowadzonej przez współczesnych prawników i etyków stale dominujące znaczenie posiada rozróżnienie św. Tomasza z Akwinu, umieszczającego sprawiedliwość w kategoriach moralnych, która zatem nie należy do porządku prawnego. Do niej odwołuje się prawo, na niej spoczywa cała konstrukcja porządku prawnego. Sprawiedliwość uznawana jest za podstawowy wyznacznik ideowy dla prawa ${ }^{27}$.

Co do prawdziwości tych twierdzeń na ogół jesteśmy zgodni, jednakże rozbieżności między prawem a przekonaniami w społeczeństwie

25 „Ius dictum est quia est iustum”, Św. Tomasz z Akwinu, Summa Theologiae, II-II q.57 a 1.

26 Sprawiedliwość, jako cnota moralna, dzięki której daje się każdemu, to co mu się należy, prowadzi do stwierdzenia, że to sprawiedliwość idzie za prawem, nie wyprzedza prawa $\mathrm{w}$ tym sensie, że funkcjonuje w relacji do prawa uprzednio istniejącego. Jak zauważa J. Hervada (Cos'é il diritto? La moderna risposta del realismo giuridico, Pontificia Università della Santa Croce, Facoltà di diritto Canonico, Subsidia Canonica 10, Roma (2013), s. 31): „Se la giustizia e la virtù di dare a ciascuno il suo, il suo diritto, affinché possa operare, é ovvio, oltreché necessario, che esista il suo di qualcuno, il suo diritto, se cosi non fosse, come potrebbe dare il tuo, il suo diritto?".

27 Wspomnieć należy, iż w chrześcijaństwie, w treści stosunku między sprawiedliwością i solidarnością wchodzi także miłość ewangeliczna - caritas, która sprawia, iż sprawiedliwość nie może mieć złudzeń, iż czyni zbytecznym caritas, a także caritas nie może dążyć do tego, aby zastąpić sprawiedliwość. F. D’Agostino, Diritto e giustizia, Per una introduzione alla studio del diritto, Milano (2000), wyd. San Paolo, s. 89: „Senza carità la giustizia é fariseismo, ma senza giustizia la carità e mera e vuota forma. Per questa ragione, il più celebrę modello di solidarieta resta nella tradizione cristiana quello di Martino di Tours, che viene incontro al medicante dividendo in due il proprio mantello [...]". 
wynikają nie tyle z braku woli bycia sprawiedliwym, co raczej odnośnie do tego, jak ma być, aby było sprawiedliwie, co robić, by oddać każdemu to, co mu się należy. Jednakże to, co się należy, nie wynika z ustaleń określonych arbitralnie przez prawodawcę, ponieważ znajduje to pierwotne zakotwiczenie w osobie ludzkiej z jej niezbywalnymi prawami.

Miara tego, co się należy, winna również uwzględniać różnorodność sytuacji każdego z uczestników relacji międzyosobowych, z których każdy cieszy się gwarancją równości. W wizerunku tym, w którym prawo odwołuje się do ideałów w sprawiedliwości, gdyż chce zaprowadzić sprawiedliwość i dąży do eliminacji przejawów niesprawiedliwości, postrzegane jest tylko jako postulat ideowy, gdyż konfrontacja z życiem i jego realiami spotyka się z wieloma rozbieżnymi ideałami sprawiedliwości. Stąd spotykamy wyrażenia określające sprawiedliwość jako dziejową, klasową, społeczną czy inne. Zdarza się, iż ci, którzy uzyskali wolność, realizują sprawiedliwość pojmowaną wedle własnej miary ${ }^{28}$. W takim układzie prawo przestaje być na usługach sprawiedliwości, lecz staje się narzędziem ucisku i nieprawości.

Jest to przejaw degeneracji prawa. Jak poucza nas historia, w wymiarze społecznym ucisk i bezprawie stają się zarzewiem buntu i kolejnych protestów wyzwolicielskich. Prawo w takich okolicznościach zdaje się zawodzić, okazuje się niewiernym sługą i ryzykownym towarzyszem w życiu człowieka.

W historii myśli prawnej stale obecne było przekonanie, iż prawo tworzone i realizowane bez sprawiedliwości bądź przeciwko sprawiedliwości nie jest prawem. Już św. Augustyn pisał, iż prawo niesprawiedliwe nie jest prawem ${ }^{29}$. Jak widać, tak jak natura człowieka, tak również prawo, które pozostaje w jego rękach, podlega skażeniu, narażone jest na pokusy różnych nadużyć skrywanych pod szyldem prawa. Tym samym dochodzimy do styku prawa i moralności.

${ }^{28}$ Książka Dale'a A. Nance'a (Law and Justice, Cases and readings on the American Legal System, Durham 1994, Introduction, s. 2) w kontekście jurysprudencji anglosaskiej na bazie wyroków sądowych podejmuje wiodące problemy na styku prawa i sprawiedliwości. Wstępne rozważania dotyczące relacji pomiędzy prawem, a moralnością są zawarte m.in. w pytaniu: „Do considerations of justice have a role in following the law? If they do, then law and justice are not as distinct as the skeptic's obiection presupposes".

29 "Lex esse non videtur quae iusta non fuerit”. De libero arbitrio. I, 5, II. 


\section{Prawo a moralność}

Wspomniano, iż porządek moralny, etyczny, religijny, prawny należą do wartości autonomicznych, z których każda w sposób sobie właściwy wpływa na kształt doświadczenia życiowego człowieka ${ }^{30}$. Autonomia nie oznacza wszakże braku wzajemnych odniesień, choć ich powiązanie, jak wykazuje historia, jest pojmowane często rozbieżnie i zależy od przyjęcia różnych przesłanek wyjściowych, dotyczących zarówno prawa, jak i moralności.

Prawo, jak wiadomo, w swojej istocie nie obejmuje w całości ludzkiej aktywności, lecz jedynie stosunki międzyosobowe, które z natury rzeczy są zawsze bilateralne: "prawo - obowiązek” i vice versa. Chodzi zatem o akty widzialne, zewnętrzne, dające się weryfikować. Prawo osiąga swój skutek odnośnie tego, co jest przypisane na mocy autorytetu władzy. Prawo adresuje się do ludzi wolnych, aby było ono skuteczne, zakłada się gotowość jego przestrzegania. Stąd uznaje się powszechnie, iż wymuszalność prawa wpisuje się w jego immanentną właściwość ${ }^{31}$. Prawo zatem, aby było skuteczne, musi podlegać sposobom wymuszania tej skuteczności. Inaczej nie spełniałoby swojej funkcji faktycznego regulatora życia społecznego. Normy prawne stawałyby się jedynie pustymi deklaracjami.

Porządek moralny ogarnia natomiast cały świat aktów osoby ludzkiej, dotyczy przejawów życia wewnętrznego i zewnętrznego, indywidualnego i społecznego, zawsze wymaga zgody sumienia w jego aktach

30 P. Gherri, Lezioni di Teologia del Diritto Canonico, Lateran University Press 2004, s. 18: „Etica, Morale, Diritto sono espressioni differenti della stessa normatività comportamentale; il loro rapporto tuttavia non é parallelo ( equivalenza tra le tre) né semplicemente gerarchico (piramidale) si tratta invece di specifiche proprie, autonome ed incrementali della stessa normatività comportamentale. L' Etica definisce cosa sia comportamento umano; la Morale definisce il comportamento umano buono; il Diritto il comportamento umano relazionalmente giusto".

31 Prawo ze swej natury sprawia obligatoryjnym to, co nakazuje, czyni tym samym zaskarżalnym jego naruszenie. Wymóg ten wymaga usprawiedliwienia, gdyż jak podkreśla S. Cotta (Giustificazione e obbligatorietà delle norme, Milano 1981, s. 21): „obbligatorietà della norma dipende dalla validità della sua giustificazione". 
dobrowolnych i świadomych ${ }^{32}$. Ujmując najprościej, na tym zasadza się różnica między imperatywem etycznym i prawnym ${ }^{33}$.

Wspólnym fundamentem dla obu pozostaje zawsze osoba ludzka, uznawana za najwyższą wartość. Na realizację dobra osoby ukierunkowany jest zatem porządek moralny i prawny. Zgodni jesteśmy co do tego, że prawo eliminuje sytuacje konfliktowe, że przyczynia się do naprawy sytuacji wyrosłych z bezprawia, że pretenduje do tego, by być uznawane za źródło zgody i pokoju.

Nie oznacza to jednak, iż prawo uwalnia człowieka od zła. Prawo nie posiada takiej mocy sprawczej. Niemniej jednak słusznie oczekuje się od prawa, aby wszystkich traktować jednakowo, bez względu na status społeczny czy stan majątkowy. Prawo nie funkcjonuje w jakimś społeczeństwie abstrakcyjnym, w którym nie ma konfliktów, nie dochodzi do ostrych sprzeczności w interesach jednostkowych i społecznych. Takiego społeczeństwa nie ma. Niemniej jednak w prawie nie istnieje kategoria wroga bądź przyjaciela. W procesach karnych występuje natomiast pojęcie sprawcy, czyli człowieka, który coś sprawił. Uznanie dla drugiego człowieka, stojące u podstaw prawa, nie wynika z altruizmu, jakby się wydawało, prawo nie odwołuje się do miłości bliźniego, lecz przyjmuje człowieka takim, jakim on jest, z jego skażoną naturą ludzką i gdy rywalizuje w ciasnej przestrzeni życiowej.

Nie miłość bliźniego, jak w chrześcijaństwie, lecz miłość własna wkomponowana jest w podstawy regulacji prawnych. Opierają się one na realnym oglądzie sytuacji każdego człowieka, który współuczestniczy i rywalizuje w ciasnej przestrzeni życiowej i ma do dyspozycji ograniczony zasób

32 Papież Jan Paweł II w swoim nauczaniu stale wskazuje na konieczność uznania osoby ludzkiej za najwyższy walor etyczny, który winien prowadzić każdą aktywność człowieka w wymiarze jednostkowym i społecznym, w tym także porządek prawny. W przemówieniu do uczestników Kongresu Prawników Katolickich Włoskich z dnia 4 grudnia 1982 r. podkreślił: „Le leggi umane trovano il proprio valore e la propria tutela solo nell' ordine morale [...] con ciò, non si vuole fare la confusione tra morale e diritto: ma si intende ricordurre questo alla sua fonte genuina, collegandolo con quei principi supremi senza i quali o contro i quali cesserebe di essere diritto". Insegnamenti di Giovanni Paolo II, V. 3, Città del Vaticano 1982, s. 1515.

33 P. Gherri, Lezioni di Teologia..., s. 19: „Il Diritto, di per sé. non obbliga in coscienza. Tuttavia la violaziona del Diritto deve sempre attivare una maggior consapevolezza e responsabilità verso i valori che la norma giuridica intende tutelare (sostanzialità della norma)”. Już w prawie rzymskim można znaleźć zasadę, według której: „De internis non iudicata praetor". 
dóbr tego świata. Stąd poszanowanie dla prawa, ponieważ uczestniczy ono i jest zarazem warunkowane etosem etycznym całego społeczeństwa. To ważne spostrzeżenie, jeśli pamięta się, że w demokratycznym państwie większość obywateli w głosowaniu daje władzę i prawo domagania się respektowania podjętych decyzji nawet przez tych, którzy ich nie akceptują. Czyni to i na tym polega specyfika demokracji poprzez formalne ujęcie w zdaniach normatywnych tego, co obowiązuje. Ich wprowadzenie zależy od społeczności, a nie np. od woli monarchy. Stąd trzeba pamiętać, iż porządek prawa i porządek moralności nie pokrywają się, choć - jak było wspomniane - moralność należy do treściowych wyznaczników, zatem prawo nie może uznać za słuszne tego, co jest złem z punktu widzenia etycznego ${ }^{34}$. Widać to wyraźnie wszędzie tam, gdzie brakuje napiętnowania zła moralnego $\mathrm{w}$ społeczeństwie, prawo otwiera wówczas drzwi do usankcjonowania tego zła w prawie. Rzymianie mówili: „summum ius summa iniuria".

\section{Wyznaczniki prawotwórcze}

Prawo zostaje zatem osadzone na tych żywotnych wartościach, które $\mathrm{w}$ danym społeczeństwie uznaje się za ważne dla zachowania własnej tożsamości, dla identyfikacji swego wizerunku w zmiennym świecie. Społeczeństwo wartości te chroni i proteguje, gdyż gwarantują one jego właściwe funkcjonowanie i zarazem zabezpieczają te oczekiwania, które społeczeństwo wiąże na przyszłość. Mówiąc prościej, z założeń ideowych danego społeczeństwa wynikają i zostają utrwalone w praktyce normy życia jednostkowego i zbiorowego w określonym miejscu i czasie.

Porządek społeczny oparty na tych dominujących przesłankach ideowych, jakie żywi dana społeczność, określa się czasami jako prawdę społeczną ${ }^{35}$. Powołaniem i zadaniem prawników staje się zatem trud prze-

34 Papież Jan Paweł II (Encyklika Veritatis Splendor (6.08.1993), n. 10) zwraca uwagę, iż autentyczna demokracja jest możliwa jedynie w państwie prawa i na bazie właściwej koncepcji osoby ludzkiej, ponadto m.in. wskazuje na ryzyko przymierza między demokracją a relatywizmem etycznym, co pozbawia współżycie obywatelskie pewnego punktu do odniesienia moralnego i zarazem pozbawia radykalnie uznania dla prawdy.

35 Warto przytoczyć w tym kontekście wypowiedź głoszoną przez przyszłego papieża J. Ratzingera, który na prawdzie zasadza prawdziwą wspólnotę i wolność człowieka. 
kuwania tej prawdy społecznej w adekwatny do niej prządek prawny. Warto przypomnieć w tym kontekście, iż prawda społeczna, podobnie jak każda prawda, staje się konkretnym faktem społecznym dzięki nadaniu jej kształtu werbalnego ${ }^{36}$. Oprócz przekazu ustnego trwałość dla prawa gwarantuje prawo pisane ${ }^{37}$, gdyż verba volant, scripta manent. Prawo, jak wiadomo, to słowo: ius dicere.

W przebiegu tego procesu zachowują stale oprócz sprawiedliwości swoje znaczenie takie wartości jak: prawda i dobro, pragnienie pokoju społecznego, ukierunkowane $\mathrm{w}$ swej istocie na samostanowienie osoby ludzkiej, na realizacji swojej tożsamości, w jej dążeniu do tego, by być sobą. Dokonuje się to w realiach życia społecznego, ekonomicznego, technicznego i innych. Mówiąc ogólnie, w całym kontekście cywilizacyjnym danego społeczeństwa.

Prawo jawi się jako dobro będące własnością wszystkich, jako wartość wysoko ceniona z racji jej specyficznej funkcji, jaką pełni ono przy realizacji innych wartości. Ocena wartościująca dokonuje się bowiem poprzez odniesienia do innych wartości, coś jest wartościowego z racji zajmowanego miejsca w systemie wartości. Prawo jest wysoko cenione z tego względu, iż należy do wszystkich, jest wartością, w której uczestniczą wszyscy. Dzieje się tak dlatego, iż jednostkowe, subiektywne „mam prawo” zostaje utrwalone jako wartość obiektywna na mocy społecznego przeświadczenia "mamy swoje prawa”. To „mamy swoje prawa” zostaje utrwalone $\mathrm{w}$ normach prawnych, które promulgowane $\mathrm{w}$ różnych dokumentach wchodzą w skład ogólnie rozumianego fenomenu prawa ${ }^{38}$.

J. Ratzinger, Cantate al signore un canto nuovo saggi di cristologia e liturgia, Milano 1996, s. 199: „La passione per la verità è il presupposto per una vera comunione. Essa deve essere portata ogni giorno. Solamente nella umile pazienza della verità possiamo maturare dall' interno, divertiamo liberi da noi stessi e liberi per Dio".

36 Sprawiedliwość jako cnota materializuje się w prawie, należy do istoty prawa, stąd w definicji św. Tomasz z Akwinu, który odwołuje się do myśli Arystotelesa i doświadczenia prawników rzymskich, definiuje prawo jako: „ipsam rem iustam” (rzecz sprawiedliwa sama w sobie). Summa Theologie, II-II, q 57, a.1 ad 1.

37 B. Montanari, Normazione umana e oggettività, w: Diritto divino e legislazione umana a cura di A. Filipponio, R. Coppola, Torino 1998, s. 181.

38 Jak ilustruje to J. Hervada, (Cos' é il diritto?..., s. 49): „Życie ludzkie wymaga, aby rzeczy, dobra, funkcje, stanowiska itd. podlegały dystrybucji, a zatem w konsekwencji przyznane różnym podmiotom; stąd rodzi się to: «co moje», "co twoje». Nie wszystko bowiem przynależy do wszystkich, tego domaga się wymóg społeczny: «non tutto é di tutti»". Dystrybucja rzeczy wynika z prawa. Skoro istnieją prawa, istnieje również «L'arte 
W praktyce ten optymistyczny obraz porządku prawnego należy bardziej do rzeczywistości postulowanej. Chcielibyśmy, aby tak było. Wiemy bowiem, iż dzięki akceptacji społecznej prawo staje się własnością społeczną, dobrem wysoko cenionym. Stąd z prawem wiązane były niejednokrotnie oczekiwania przekraczające możliwości prawa. Sprowadzało się to do przerostu prawa, a w rezultacie do ujurudycznienia życia społecznego. Można wspomnieć w tym kontekście o zjawiskach negatywnych, które wywołują niejednokrotnie dewastacyjny wpływ na procesy humanizacji życia. Dzieje się tak m.in. wówczas, gdy na mocy tzw. „woli politycznej”, w zapędach reformatorskich, dochodzi do rozchwiania i demontażu równowagi w trójpodziale władzy: prawodawczej, wykonawczej i sądowniczej.

Gdy brak synchronizmu między przepisami prawa a przekonaniami dominującymi w świadomości społecznej, determinującymi odmienny sposób postępowania ludzi, zdarzają się sytuacje, w których zachodzi rozbieżność między prawem a życiem. Rozdźwięk zachodzi wówczas, gdy społeczeństwo nie utożsamia się z wartościami, na których bazuje prawo.

W świetle tych wywodów odsłania się skomplikowany i zarazem wieloraki w postulowanych rozwiązaniach problem prawdy, która winna być wpisana $w$ treści porządku prawnego ${ }^{39}$. Zgodni jesteśmy co do stwierdzenia, iż współżycie ludzi między sobą winno być oparte na prawdzie, która ogarnia całość kontekstu kulturowego człowieka. Prawo bowiem tylko w takiej relacji do prawdy przyczynia się do humanizacji życia. Każde zatem kłamstwo, na którym wspiera się prawo, dewastuje samą naturę prawa, jest kamuflażem prawa i rodzi w konsekwencjach przemoc. Deklarowana zgodność co do tych ogólnikowych twierdzeń nie przesłania wszakże całego kompleksu problemów, jakie powstają na styku prawa i prawdy. Dzieje się tak głównie dlatego, iż żyjemy w pluralistycznym społeczeństwie zróżnicowanym ideowo i niepogodzonym co do samego pojmowania prawdy ${ }^{40}$.

del diritto», która należy do wartości pierwotnych i fundamentalnych. Zatem prawo uznawane jest za dobro pierwszej potrzeby («é un bene di prima nocessità»)".

39 Wyraźnie naucza o tym papież Jan Paweł II, wskazując, iż porządek prawny winien być podporządkowany prawdzie. Powinien być napełniony prawdą, im bardziej jest zanurzony w prawdzie, tym bardziej prawo przyczynia się do humanizacji życia, im bardziej jest budowany na kłamstwie, tym mocniej staje się przemocą. Zob. Giovanni Paolo II, La verità, forza della pace, L'Osservatore Romano z dnia 19 grudnia 1979 r.

40 Doświadczenie wojen religijnych toczonych w imię prawdy nakazywało usunąć problem ze sfery politycznej. Jako fundament nowoczesnego państwa przyjęto 
Pytanie Piłata podczas procesu nad Jezusem: cóż to jest prawda ${ }^{41}$, pomimo upływu wieków nie traci nic ze swojej aktualności. Warto dodać, iż w doktrynie chrześcijańskiej wyraźnie akcentowany jest obowiązek człowieka do poszukiwania prawdy, do przylgnięcia do prawdy, choć zarazem wyróżnia się jasno odrębność porządku prawnego od moralności ${ }^{42}$. Niemniej jednak prawo winno umożliwiać życie $\mathrm{w}$ zgodzie $\mathrm{z}$ poznaną prawdą. Znany aksjomat często przywoływany w prawie głosi: „Veritas est basis, fundamentum seu mater iustitiae" ${ }^{\prime \prime 3}$.

Demokratyczne państwo prawa na bazie bolesnych doświadczeń historycznych, w których spór o prawdę prowadził niejednokrotnie do konfliktów wojennych, eliminuje problem prawdy ze sfery politycznej. Na sztandarach nowoczesnego państwa, zrodzonego z ideałów epoki oświecenia, dominują natomiast hasła wolności i równości zagwarantowane dla wszystkich obywateli. Na tych właśnie wartościach powstawała nowa wizja państwa demokratycznego i tworzonego w nim prawa.

W przeszłości nie zajmowano się problemami z zakresu dzisiejszej aksjologii prawa i jego relacjami z moralnością. Obraz wydawał się być prosty. To monarcha legitymujący źródło swojej władzy w autorytecie Boga rządził poddanym mu ludem, sprawował nad nim opiekę, dbał o jego dobro

zapewnienie pokoju między ludźmi, niepogodzonymi co do prawdy. Etos demokratycznego państwa zasadza się więc na gwarancjach wolności i podleganiu tworzonego przezeń prawa, nie daje patentu na prawdę, nie pozbawia zatem prawa do własnego zdania tych, co nie podzielają przekonań większości. Ograniczenia wobec większości stawia właśnie wolność i równość wszystkich. Szerzej m.in. E. Böckenförde, Etos nowoczesnej demokracji a Kościót, w: Wolność - państwo - Kościót, wybór i tłum. P. Kaczorowski, Kraków 1994, s. 23-44.

41 Ewangelia św. Jana, 18,39: „Jam się na to narodził i po to przyszedłem na świat, aby dać świadectwo prawdzie. Każdy, kto jest z prawdy słucha mego głosu. Mówi mu Piłat: co to jest prawda? Po tych słowach wyszedł [...]".

${ }^{42}$ Kościół katolicki na Soborze Watykańskim II uznał, iż w sprawach przekonań ludzie winni być wolni od przymusu ze strony innych ludzi, zbiorowości czy jakiejkolwiek innej władzy, prawda zaś nie narzuca się inaczej, jak tylko siłą samej prawdy. Sobór Watykański II, Deklaracja o wolności religijnej „Dignitatis humanae” (7.12.1965), w: Sobór Watykański II, Konstytucje. Dekrety. Deklaracje. Tekst polski. Nowe tłumaczenie, Poznań 2002, n. 2. Oznacza to rozróżnienie między porządkiem prawnym a obowiązkiem moralnym. Poszukiwanie prawdy jest obowiązkiem moralnym, prawo zaś umożliwia żyć każdemu w zgodzie z poznaną prawdą.

43 A. Barbosa, De Axiomatibus Iuris usufrequentoribus. Axioma 224, Veritas in Tractatus Varii, Lugduni 1678, s. 136. 
doczesne i duchowe, stanowiąc prawa, wskazywał, jak mają żyć. Poddani zaś mieli obowiązek przestrzegania prawa wydanego przez ich władcę.

Sytuacja odmieniła się diametralnie w państwie demokratycznym. $\mathrm{Na}$ jego czele nie stoi władca, nie ma panującego i poddanych, władza należy do obywateli. Struktura państwa demokratycznego zasadza się ponadto na trójpodziale władzy. Prawo tworzone jest oddolnie, w demokracji prawo stanowi lud, który składa się z obywateli równych i wolnych (zróżnicowanie $\mathrm{w}$ demokracji bezpośredniej i pośredniej posiada znaczenie wtórne). W demokratycznym państwie o tym, co jest prawem, stanowi większość, która nie rości sobie pretensji do orzekania o tym, co dobre, a co złe etycznie. Decyzja większości stanowi jedynie o tym, co jest legalne. Sytuacja ta rodzi wszakże niezwykle poważny problem, jeśli pamięta się, iż opierając się na powszechnym przekonaniu, nie ma zgody na to, aby czyn zły, np. zbrodnia, stawał się czymś godziwym poprzez fakt, iż zostaje on uznany przez zgodę większości jako czyn prawomocny chroniony przez prawo. W tym miejscu wydaje się, iż odsłania się słaby punkt, tzw. pięta achillesowa demokracji. Postuluje ona pytanie o to, kto decyduje o tym, co jest dobre, a co złe moralnie.

W demokracji jej strukturalny etos wyraża się w tym, iż wszystkie poglądy propagowane przez poszczególne osoby i przez partie polityczne mają równe, tzn. takie samo prawo do politycznego istnienia, w konsekwencji nikt nie ma prawa do zgłaszania roszczeń, by jego poglądy były uznawane za ważniejsze od innych. System demokracji wspiera się bowiem na wspomnianych wyżej zasadach wolności i równości wszystkich obywateli, bez względu na ich przekonania polityczne, etyczne czy religijne. W wyborach ważna jest jedynie liczba głosów - wszystkie mają tę samą wartość. Ich wynik, uzyskana większość głosów, daje prawo do domagania się poszanowania podjętych rozstrzygnięć zapadłych głosami większości, nawet przez tych, którzy ich nie akceptują. Jednakże zasada demokratycznego państwa nakazująca uznać decyzje większości za wiążące, stawia zarazem granicę dla uprawnień większości. Liczba bowiem oddanych głosów nie przesądza o słuszności decyzji powziętej przez większość obywateli. Odwołując się zatem do zasad wolności i równości wszystkich obywateli, nie wolno pozbawiać własnego zdania tych, którzy znajdują się w mniejszości. Liczba oddanych głosów nie determinuje zarazem wyznawanych przekonań czy posiadanych kwalifikacji przez obywatela w demokratycznym państwie. Gwarantuje się tym samym obszar wolności, na którym legitymują swoją aktywność m.in. kościoły i związki 
wyznaniowe. Ich działalność religijna nie jest zatem rezultatem koncesji ze strony władzy wybranej w demokratycznych wyborach ${ }^{44}$.

Wspomniano, iż bezpośrednim celem prawa nie jest umoralnianie człowieka, pomimo tego prawo znajduje przecież solidne oparcie $\mathrm{w}$ jego etosie moralnym. Gdy brak tego poparcia, rodzą się konflikty sumienia, zachodzi dychotomia między przekonaniami a czynami wymaganymi przez prawo. Obywatel często znajduje się na rozdrożu, traci orientację co do właściwej oceny sytuacji, w której się znalazł. Zazwyczaj, gdy brakuje jasnych kierunkowskazów, ucieka się do swoistego alibi: to, co prawem dozwolone, uznaje się zarazem za etycznie godziwe. Tym sposobem niepokój sumienia przegrywa z legalizmem.

\section{Zakończenie}

Okazuje się, iż prawo przedstawia bardzo skomplikowane doświadczenie życiowe. Prawo tworzenia prawa jest sztuką: "ars legesferendi”. W doświadczeniu tym dotyka się najgłębszych treści, które ożywiają jego istotną tkankę $e^{45}$. Zadziwia swoista antynomia takich wartości jak m.in.: autonomia i podległość, indywidualizm i socjalność, abstrakcyjność i konkretność, interioryzacja i uzewnętrznienie. Ta antynomia wydaje się zarazem nie do usunięcia, gdyż poprzez te zjawiska przebiega całość procesu transformacji prawa przejmowanego ze świata ideałów do świata jego konkretnej realizacji. Prawo w swojej konkretności nie opisuje jednakże rzeczywistości, nie jest fotografią społeczeństwa i wiernym zapisem

44 Należy dostrzec w tym względzie, iż prawo wprowadza porządek dzięki jednoznaczności regulowanych zachowań, tych oczekiwanych i zarazem sankcjonowanych przez społeczność. Są to zatem sankcje społeczne, których wprowadzenie zależy od społeczności. Demokracja otwiera więc przestrzeń, w której może być realizowana misja Kościoła, powołanego do głoszenia prawdy, poprzez zaangażowanie wiernych i ich świadectwo o wyznawanej prawdzie, korzystając z demokratycznych zasad wolności i równości.

45 S. Cotta (Il Diritto Come Sistema di Valori..., s. 37) uznaje za oczywistą relację między prawem a wartością, gdyż nie można żyć w społeczeństwie bez prawa, człowiek nie mógłby żyć wyobcowany z jakiejkolwiek formy życia zbiorowego bez obawy o degradację do poziomu zwierząt. To pokazuje wystarczająco, jak wielkie znaczenie posiada prawo dla ludzkiej kondycji. Stanowi ono wartość, która jest godna człowieka i dla człowieka: („il diritto [...] il suo esser valore, se é vero che la parola «valore» designa ciò é degno dell’ uomo per l'uomo"). 
zjawisk, poprzez które ono się objawia. Mówiąc prościej, prawo nie mówi jak jest, lecz jak być powinno. Nie oznacza to prawotwórczego woluntaryzmu, gdyż porządek normatywny winien odpowiadać porządkowi obiektywnemu. Sprawia to, iż norma jest stwierdzeniem pewnej powinności, a nie dopiero jej ustanowieniem. Ilustruje to znane sformułowanie: sollen znajduje swoje uzasadnienie w sein.

Wiadomo, że procesy prawodawcze przechodzą drogę od opisu do przepisu, to jednak prawo ze swojej istoty wyraża to, co powinno być. Ingerencja prawa nakazuje czynić w określony sposób. Spośród wielu możliwości wyboru działania prawo stanowi i czyni uprzywilejowanymi tylko te zachowania, które określa, czyni je zarazem obowiązkowymi, z możliwością ich egzekucji. Tą drogą rzeczywistość społeczna, polityczna, ekonomiczna zostaje ujęta w struktury prawne. Pod tym względem prawo określając, jak być powinno, ukierunkowane jest zarazem na przyszłość: „Lex respicit futura”, liczy na szansę przemiany człowieka w jego wymiarze jednostkowym oraz społecznym, na jego rozwój i pomnażanie dorobku dziedzictwa historycznego.

Nie jest to mało, jeśli pamięta się, że nawet najlepsze prawo narażone jest na niebezpieczeństwo nadużyć. Prawo bowiem, jako dzieło człowieka, partycypuje siłą rzeczy w przejawach skażonej natury ludzkiej, stąd częsta uwaga, iż najsłabszym ogniwem prawa jest człowiek.

W rozwoju cywilizacji europejskiej, tak w przeszłości, jak i obecnie, prawo służy humanizacji życia, jest wartością wysoko cenioną ${ }^{46}$.

Być może sens podjętych tu rozważań w jakiejś mierze ilustruje porównanie prawnika zajmującego się normami prawa z sytuacją, w której pełni swoje powołanie lekarz. Lekarz staje nad chorym, aby go leczyć, a nie zajmować się wypisywaniem recept, choć proces leczenia następuje poprzez wypisywanie lekarstw. Nie zostaje się wszakże lekarzem po to, aby wypisywać recepty, lecz by leczyć chorego. Podobnie prawnik nie może swojej uwagi ograniczać do świata norm, lecz poprzez normy i ich aplikację czynić świat bardziej sprawiedliwym i godnym człowieka. Prawnik zatem w sposób dla prawa właściwy współuczestniczy w procesie humanizacji

${ }^{46}$ R. Sobański, Europa obojga praw, Katowice 2006, s. 19: „Prawo wyróżnia Europę: Europa to kontynent - od początku jego wykrystalizowania się, jako Europa - na którym ceni się prawo. Badania historyków i etnologów wykazały, że tak wysoka ocena prawa jest charakterystyczna dla cywilizacji europejskiej". 
życia ludzkiego, podejmuje niezwykle szlachetny wysiłek rzeźbienia wizerunku człowieka o prawdziwie ludzkim obliczu.

\section{Bibliografia}

Barbosa A., De Axiomatibus Iuris usufrequentoribus. Axioma 224, Veritas in Tractatus Varii, Lugduni 1678.

Berman H.J., Diritto e rivoluzione. Le origini della tradizione giuridica occidentale, Bologna 1998.

Bertolino R., L'obiezione di coscienza moderna. Per una fondazione del diritto di obiezione, Torino 1994.

Böckenförde E., Etos nowoczesnej demokracji a Kościót, w: Wolność - państwo - Kościót, wybór i tłum. P. Kaczorowski, Kraków 1994.

Burczak K., Ius sequitur vitam as a principle of evolution and revision of the law, w: Hodie et Cras, Today and Tomorrow of the 1983 Code of Canon Law Thirty Years after Promulgation, Lublin 2015.

Cotta S., Giustificazione e obbligatorietà delle norme, Milano 1981.

D'Agostino F., Diritto e giustizia, Per una introduzione alla studio del diritto, Milano 2000.

di Rievaulx A., Amicizia spirituale, w: L'Amicizia Spirituale, Introduzione, Traduzione e Commento di D. Pezzini, Milano 1996.

Fioravanti M., Costituzione, il Mulino, Bologna 1999, Istitutio Italiano per gli studi Filosofici, I valori della Costituzione Italiana, Atti del Convegno La Costituzione della Repubblica oggi, Principi da custodire, Istituti da Riformare, Napoli 20 Maggio 1995, red. S. Marotta, La Città del Sole 1996.

Gerosa L., Esperienza del diritto ed esperienza di fede al banco di prova di un nuovo manuale di diritto canonico, Rivista Teologica di Lugano 1(1998).

Gherri P., Lezioni di Teologia del Diritto Canonico, Città del Vaticano 2004.

Giovanni Paolo II, La verità, forza della pace, L'Osservatore Romano z dnia 19 grudnia $1979 \mathrm{r}$.

Grossi P., Prima Lezione di diritto, Roma 2003.

Hervada J., Cos' é il diritto? La moderna risposta del realismo giuridico, Roma 2013.

Insegnamenti di Giovanni Paolo II, V. 1, Città del Vaticano 1982.

Insegnamenti di Giovanni Paolo II, V. 3, Citta del Vaticano 1982.

„Iustiniani Augusti Digesta seu Pandectae".

Krukowski J., Kościót i państwo. Podstawy relacji prawnych, Lublin 1993.

Kupiszewski I., Prawo rzymskie a wspótczesność, Warszawa 1988. 
Lener S., Coesistenza e società: fondamento ontologico dell diritto, Civilta Cattolica 134(1983).

Montanari B., Normazione umana e oggettività, w: Diritto divino e legislazione umana, red. A. Filipponio, R. Coppola, Torino 1998.

Nance D.A., Introduction, w: "Law and Justice", Cases and readings on the American Legal System, Durham 1994.

Ratzinger J., Cantate al signore un canto nuovo saggi di cristologia e liturgia, Milano 1996. Readings, Cases, Materials in Canon Law, a textbook for Ministerial Students, Revised Edition, red. J. Hite, D.J. Ward, Collegeville 1990.

Realizzare insieme un "progetto d'uomo" veramente umano, La Civiltà Cattolica 132(1981), nr 1.

Sobański R., Europa obojga praw, Katowice 2006.

Sobański R., Prawo moralne a procesy prawotwórcze demokratycznego państwa prawa, Śląskie Studia Historyczno-Teologiczne 29(1996).

Sobański R., Prawo: wyzwolenie czy ucisk?, Chrześcijanin w Świecie 26(1997), nr 3(204).

Sobański R., Prawo w Europie, Śląskie Studia Historyczno-Teologiczne 31(1998).

Spadaro A., Contributo per una teoria della costituzione, w: Fra democrazia relativista e assolutismo etico, Milano 1994.

Św. Tomasz z Akwinu, Summa Theologiae II-II q.57 a 1.

Waldstein W., Teoria Generale del Diritto, Dall' antichita ad oggi, Roma 2001.

\section{Streszczenie}

Artykuł zamierza wykazać wpływ prawa na procesy humanizacji życia w wymiarze osobowym i społecznym.

Prawo to powszechne doświadczenie wszystkich ludzi, jest tworzone przez człowieka i dla człowieka: „cum igitur hominum causa omne ius constitutum sit”.

Fundament prawa opiera się na jednakowej i niezbywalnej godności osoby ludzkiej. Człowiek posługuje się prawem w wysiłku realizacji swego człowieczeństwa i lepszej przyszłości.

Prawo to także kluczowy regulator życia społecznego, prawo konsoliduje więzi społeczne, wzmacnia struktury państwa, tworzy wspólnotę narodów.

Humanizację prawa objawia jego wyzwalająca funkcja. Prawo stanowi oparcie dla słabszych, człowiek swojej pozycji nie musi bronić siłą, jego miejsce w społeczeństwie gwarantuje mu prawo. Dzięki prawu w sytuacjach konfliktowych został wygaszony dźwięk broni.

Człowiekowi w poszukiwaniu procedur organizacji życia przyświeca idea zawarta w twierdzeniu Anaksymandera z Miletu, iż człowiek pragnie być sobą, człowiek zabiega o kształt swego losu. 
Prawo dąży do realizacji sprawiedliwości, chce oddać każdemu to, co mu się należy. Prawo nie utożsamia się z moralnością - to jednak nie może uznać za słuszne tego, co jest złem z punktu widzenia moralnego.

Prawo odwołuje się do prawdy, choć prawdy nie dekretuje, to jednak prawo oparte na kłamstwie byłoby destrukcją samego prawa.

W demokratycznym państwie o tym, co jest prawem, stanowi większość obywateli. Większość głosów nie orzeka o prawdzie, nie stanowi o tym, co dobre, a co złe etycznie. Decyzja większości stanowi o tym, co jest legalne.

System demokracji opiera się na zasadach wolności i równości wszystkich obywateli. Dzięki tym zasadom respektuje się zarazem zdania tych, którzy są w mniejszości.

Tworzenie prawa jest sztuką ,"ars legesferendi". Prawo nie jest fotografią społeczeństwa, prawo nie mówi, jak jest, lecz jak być powinno; stąd „lex respicit futura”.

Prawo liczy na szansę przemiany człowieka, na budowę świata o bardziej ludzkim wizerunku.

Prawnika można porównać z powołaniem lekarza. Lekarz staje nad chorym, aby go leczyć, a nie zajmować się wypisywaniem recept, choć proces leczenia następuje poprzez wypisywanie recept.

Podobnie prawnik nie może ograniczać swojej uwagi do świata norm, lecz poprzez normy i ich aplikację czynić świat bardziej sprawiedliwym i godnym człowieka.

Słowa kluczowe: proces humanizacji, godność człowieka, jednakowa i niezbywalna godność osoby, wyzwalająca funkcja prawa, demokratyczny system, zasady wolności i równości, regulator życia społecznego, wypisywanie recept, świat bardziej sprawiedliwy

\section{LAW IN THE SERVICE OF HUMANIZATION OF LIFE}

\section{Summary}

The article intends to demonstrate the impact of law on humanization processes of life in the personal and social dimension.

The law, this universal experience of all people, is created by man and for man: "cum igitur hominum causa omne ius constitutum sit". The foundation of law is based on the equal and inalienable dignity of the human person. Man uses the law in the effort to realize his humanity and a better future.

The law is also a key regulator of social life, the law consolidates social bonds, strengthens the structures of the state, creates a community of nations.

Humanization of the law is revealed by its liberating function. The law can be the support for the weak, a man does not have to defend his position, his place 
in society guarantees him the law. Thanks to the law, the weapon's sound was muted in conflict situations.

Man in search of procedures for organizing life is guided by the idea contained in the theorem of Anaximander of Miletus that man desires to be himself, man strives to shape his fate.

The law strives for justice and wants to give everyone its due. The law does not identify with morality - but this cannot be considered as right what is evil from a moral point of view.

The law refers to the truth, although it does not decree the truth, but the law based on lies would be the destruction of the law itself.

In a democratic state, what is the law is up for the decision the majority of citizens. Most voices do not rule in accordance with the truth, they do not determine what is good and what is ethically wrong. The majority's decision is what is legal.

The democracy system is based on the principles of freedom and equality of all citizens. Thanks to these principles, the opinions of those who are in the minority are respected.

Creating the law is the art of "ars legesferendi". The law is not a reflection of society, the law does not say how it is, but how it should be; hence the "lex respicit futura".

The law counts on the chance of human transformation and building a world with a more human image.

A lawyer's mission can be compared to vocation of a doctor. The doctor stands over the patient to treat him and not deal with writing prescriptions, although the treatment process is done by writing prescriptions. The comparison with the role of the doctor emphasizes this idea: the doctor writes a prescription, but it is not the prescription that heals, but the drug. Similarly, in a legal norm, it is not about the letter, the spirit of the law. The Scriptures say that the letter kills and the spirit gives life. Hence we are talking about the spirit of the law.

Key words: humanization process, human dignity, equal and inalienable dignity of the person, liberating function of law, democratic system, principles of freedom and equality, social life regulator, writing prescriptions, a more just world

\section{ПРАВО НА СЛУЖБЕ ГУМАНИЗАЦИИ ЖИЗНИ}

\section{Резюме}

В статье будет продемонстрировано влияние закона на процессы гуманизации жизни в личном и социальном измерении.

Закон, общий опыт всех людей, создается человеком и для человека: «cum igitur hominum causa omne ius constitutum sit». 
В основе права лежит равное и неотъемлемое достоинство человеческой личности. Человек использует закон, чтобы осознать свою человечность и лучшее будущее.Право также является ключевым регулятором общественной жизни, закон укрепляет социальные связи, укрепляет структуры государства, создает сообщество наций.

Гуманизация права проявляется в его освободительной функции. Закон - опора для более слабых, человеку не обязательно защищать свое положение силой, его место в обществе гарантируется законом. Благодаря закону в конфликтных ситуациях не применялось оружие.

В поисках процедур организации жизни человек руководствуется идеей, содержащейся в теориях Анаксимандра Милетского: что человек хочет быть самим собой, человек стремится определять свою судьбу.

Закон стремится добиться справедливости, он хочет дать каждому то, что ему причитается. Закон не отождествляется с моралью - но он не может считать правильным то, что неправильно с моральной точки зрения.

Закон ссылается на истину, хотя он не определяет истину, но закон, основанный на лжи, разрушит сам закон.

В демократической стране сущность закона определяет большинство граждан. Большинство голосов не определяет истины и того, что этически правильное или неправильное. Решение большинства определяет, что является законным.

Демократическая система основана на принципах свободы и равенства всех граждан. Благодаря этим правилам также уважается мнение тех, кто находится в меньшинстве.

Законодательство - это искусство «ars legesferendi». Закон - это не изображение общества, закон не говорит о том, как есть, но как должно быть; отсюда «lex respicit futura».

Закон рассчитывает на шанс изменить человека, построить мир более человечным.

Юриста можно сравнить с призванием врача. Врач стоит над больным, чтобы лечить его, а не выписывать рецепты, хотя процесс лечения происходит посредством выписывания рецептов.

Точно так же юрист не может ограничивать свое внимание миром норм, но с помощью норм и их применения делать мир более справедливым и достойным человека.

Ключевые слова: процесс гуманизации, человеческое достоинство, равное и неотъемлемое достоинство человека, освободительная функция закона, демократический строй, принципы свободы и равенства, регулятор общественной жизни, выписывание рецептов, более справедливый мир 
